\title{
PANTANG LARANG AND THE ENVIRONMENTAL WISDOM OF SAMBASNESS MALAY IN THE SEPINGGAN VILLAGE
}

\author{
Syamsul Kurniawan \\ Institut Agama Islam Negeri Pontianak \\ syamsulkurniawan001@gmail.com
}

\begin{abstract}
Based on the research, Sambasness Malay in Sepinggan Village recoqnize pantang larang (prohibition/taboo) as moral norms or unwritten rules dealing with their activities as Malay. it is called pantang larang because it contains prohibition. If someone breaks the rules of pantang larang, he or she will get bad or scary thing. At sepinggan village, pantang larang developed as a strategy for malay in educating character building indeed since early childhood. The environmental wisdom is one of things which reflected in Sambasness Malay's pantang larang at Sepinggan Village. It has been known for a long time from desecent untill now and internalized assimilated in their activities as moeslims. it is descriptive research. it describes objective and contextual that information source gains from the field observation.
\end{abstract}

Abstrak

Berdasarkan penelitian yang penulis lakukan, orang Melayu Sambas Desa Sepinggan mengenali pantang larang sebagai tata nilai atau aturan yang tidak tertulis yang mengikuti keseharian mereka sebagai orang melayu. Disebut pantang larang karena berisikan pantangan atau larangan. Apabila seseorang melanggar pantang larang konsekuensinya akan mengalami hal buruk atau menakutkan. Di Desa Sepinggan, pantang larang berkembang sebagai strategi dalam mendidikkan karakter, bahkan sejak usia dini. Kearifan lingkungan, menjadi salah satu hal yang tercermin dalam pantang larang orang Melayu Sambas di Desa 
Sepinggan. Kepercayaan ini telah berlangsung lama dan turun temurun dan menyatu dalam keseharian mereka umat Islam.

Keyword: Pantang Larang, the Environmental Wisdom.

\section{A. Introduction}

Environmental crisis has happened and become a part of general phenomenon of world society life today. It indicates, the damages of the environmental functions and vulnerable of the environmental ability. In Indonesia, as informed by Kompas, for example, every year Indonesia has lost 684.000 hectare of its forest. ${ }^{1}$ Actually our forest considered becomes as world lungs and gives kindness to human in the world, not as the opposites. ${ }^{2}$

Consequently, the area of water absorptions more decreases, the water reserves more rare, meanwhile when raining season river water over flowing and it cost flood, landslide and more other loss that people suffered. Massive murdered of Orang utan in Kalimantan, ${ }^{3}$ is other example how we tend to act destructive to environment.

The damage of environment must give special attention, ${ }^{4}$ moreover Indonesian majority is Muslim community who should has wisdom about environmental preservation efforts. We understand how Islam very advocates it adherents to environment preservation. Damaging the environment means breaking Allah SWT orders., ${ }^{5}$ and breaking it has bad consequences, ${ }^{6}$ like natural disasters.

1 Kompas, "Setiap Tahun Hutan Indonesia Hilang 684.000 Hektar", http://regional.kompas.com/read/2016/08/30/15362721/setiap.tahun.hutan.indonesia. hilang.684.000.hektar.

${ }^{2}$ Wahyu Wiriadinata, "The Indonesian Forestry in Economic, Ecosystem and Legal Perspectives", Journal of Public Administration and Governance, Vol. 4, No. 1, 2014. p. 87100.

3 Melissa Hogenboom, "Melacak Para Pemburu Orang Utan di Kalimantan", http://www.bbc.com/indonesia/vert-earth-38787128.

${ }^{4}$ Pande Made Kutanegara, Membangun Masyarakat Indonesia Peduli Lingkungan (Yogyakarta: Gadjah Mada University Press, 2014), p. 1.

5 "And cause not corruption upon the earth its reformation and invoke Him in fear and aspiration, indeed the Mercy of Allah is near to the doers of good" (QS al-A'raf/07: 56).

${ }^{66}$ Mischief has appeared on land and sea because of (the meed) that the hands of men have earned, that Allah may give them a taste of some of their deeds in order that they may turn back (from evil) (QS ar-Ruum/40: 41). 
Growing environmental wisdom based on religion belief certainly not necessarily the duty of Islam teachers at school, 7 but our responsible whether family or society. All three must synergize and integrated in one package of ikhtiar in character building. ${ }^{8}$ This matter means community, have a stake in growing environmental wisdom of it citizens. ${ }^{9}$

On Sambasness Malay in Sepinggan village of Sambas Regency for example, they have pantang larang that embraced in their daily life. Pantang larang life as part of local wisdom of Malay ${ }^{10}$ in this area, as part of their local wisdom as Islam people. Surely, that as authentic pantang larang unrecognized in Islam teachings, however this matter easy for us to understand considering the flexible of Islam religion characters, so able to blend and merge with culture, era even society environment anywhere. ${ }^{11}$

Based on the research that writer conducted throughout 2015 until mid 2016 in Sepinggan Village, Semparuk Subdisctrict, Sambas Regency West Kalimantan province, Sambasness Malay Sepinggan village recognizing pantang larang as values or unwritten rules that following their daily as Malay people. Called as pantang larang because containing taboo or ban. If someone breaking pantang larang the consequences will experience bad thing or terrifying. In Sepinggan village, pantang larang developing as

7 Syamsul Kurniawan, "Penguatan Kearifan Lingkungan Melalui Pelajaran Pendidikan Agama Islam di Sekolah", Jurnal At-Turats, Volume 7, Nomor 2, Desember 2013, p. 91.

${ }^{8}$ See Syamsul Kurniawan, "Konsep dan Implementasi Pendidikan Karakter di Lingkungan Keluarga, Sekolah dan Masyarakat”, Jurnal At-Turats, Volume 6, Nomor 1, Desember 2012.

${ }^{9}$ Syamsul Kurniawan, Pendidikan Karakter (Yogyakarta: Arruzz Media, 2013), p. 217.

${ }^{10}$ Definition of Malay in this context is showing a group of ethic in the community that still believe in ritual and tradition of Malay belief that is Islam. As Hermansyah argued that the Malay means followers of Islam. Hermansyah, Islam dan Melayu di Borneo (Pontianak: IAIN Pontianak Press, 2015), p. 1. According to this view Islam is a marker of a person's Malay identity.

${ }^{11}$ Syamsul Kurniawan, "Pantang Larang dalam Pendidikan Karakter Pada Anak Usia Dini Orang Melayu Sambas Desa Sepinggan”, in International Conference Proceeding, IAIN Pontianak, April 2017, p. 71. 
strategy in character building, ${ }^{12}$ which educated since early ages, ${ }^{13}$ whether through parents teaching and through association or interaction in society.

Environmental wisdom, becomes one of teaching in pantang larang Sambasness Malay in Sepinggan village. This teaching has been long take place and hereditary and blend in Islam people daily life at this area. Until now, this teaching still be practiced in Sambasness Malay and Islam people in daily. Because of it, becomes it reason to do the research. This research character is descriptive in understanding, describing situation only (investigated object) as it is and contextual as information source that researcher has in the field, that is about pantang larang and environmental wisdom of Sambasness Malay in Sepinggan Village.

\section{B. Geographic and Demographic Condition of Sepinggan Village Sambas Regency}

Before getting to the core of the discussion, first of all, writer need to provide a general description of the geographic and demographic characteristics of the Sepinggan Village. This is because there is a belief that the growth and development of local wisdom is inevitable due to the community or the environment that support it. ${ }^{14}$

Administratively, the village is located in Sepinggan Village, Semparuk Subdistrict, Sambas Regency, West Kalimantan. Name of Sepinggan village taken from crop failure situation that ever happened to the people in this village, that the result from the crop only produced a plate of (sepinggan) rice. Because of it, the name of this village is Sepinggan..$^{15}$ To come to the Sepinggan village, from Pontianak city we can through it from land path and it takes more less 5 until 6 hours. Mostly the people that

12 Syamsul Kurniawan, "Pantang Larang in the Sepinggan Village Muslim Community from the Perspective of Character Education”, Ta'dib, Volume 21, Nomor 2, Desember 2016, p. 114.

${ }^{13}$ More see Syamsul Kurniawan, "Pantang Larang dalam ..., p. 68-76.

${ }^{14}$ Gasthoul Bothoul, Teori-Teori Filsafat Sosial Ibn Khaldun (Jakarta: Titian Ilahi Press, 1998), p. 39-43.

15 Nasiana, dkk., Asal-Usul Sepinggan: Antologi Cerita Rakyat Semparuk (Pontianak: Balai Bahasa Kalimantan Barat, 2016), p. 1-7. Information about the origin of Sepinggan Village sourced from the situation of crop failure that happened to this village, also told by H. Asmuni ( 80 years old), the elders of Malay community of Sepinggan village (based on interview on February 14,2015. At Sepinggan village). 
domicile in this village is Sambasness Malay. In general, the climatic conditions in Sepinggan village are not much different from other places in Sambas Regency, and other areas in West Kalimantan. It has a tropical climate, so that the air temperature in this area is relatively hot.

The definitions of Malay in this paper refers to an ethnic group in society that still observes rituals and traditions and belief of the Malay (i.e. Islam). This relevant to the teory from Hermansyah, ${ }^{16}$ that said Malay refers to people as Muslim. Refers to this teory, Islam as someone Malay identity marker. It also can be said, the Malay identity refers to people who are Muslims that still practicing the traditions or adat-istiadat (customs) Sambasness Malay in daily life. From the aspects of language, the Sambasness Malay of Sepinggan village use the Sambas Malay in communicating, as particularly Malay society.

In terms of family relationship, Sambasness Malay in Sepinggan village hold to the bilateral or parental principle, by adopting an extended family system. Parental or bilateral principle is a balanced kinship system through great grandfather and grandmother. ${ }^{17}$ extended family system is a family core added importance relatives such as grandfather, grandmother, aunt, uncle etc ${ }^{18}$

This system refers to a balanced kinship between patrilineal and matrilineal lines. Father and mother therefore equal in the eye of a child, although the backbone of the family is still the father. This means that a father has a higher honor and is very decisive in making difficult decision in a family. Beside the core family, in one household often there are also in laws and brother or sisters in law.

A father is the main worker and protector of the family. While a mother the person in charge of the household. Children become dependent from parents until they are able to support themselves or getting married/ married. In the Malay Sepinggan village community also has the terms 'close relative' and 'distant relative' based on the closeness of kinship or blood relation.

${ }^{16}$ Hermansyah, Islam dan Melayu di Borneo (Pontianak: IAIN Pontianak Press, 2015), p. 1.

${ }^{17}$ Soerjono Soekamto, Kamus Sosiologi (Jakarta: Rajawali Press, 1993), p. 56.

${ }^{18}$ Hartini dan Kartasapoetra, Kamus Sosiologi dan Kependudukan (Jakarta: Bumi Aksara, 1992), p. 140. 
In religious Islam practicing masse by the Malay of Sepinggan village. This matter seen from the fact that many worshipers in every mosque, especially during Friday prayer. Socialization of religious teaching has started from an early ages. Religious dakwa is often carried out, especially on Islamic holy days. Each ceremony is also conducted in Islam way, at least with the recitation from religious leaders. Even though, the remains of animism and dynamism in the past still exist, and it appears in most forms of developing local wisdom, such as the rituals of tepung tawar, ngantar ajjong, bepappas, serapah and pantang larang, or people belief about spells (mantra) ${ }^{19}$ which are originally unknown in the teachings of Islam. ${ }^{20}$

\section{Pantang Larang as a Local Wisdom of The Sambasness Malay of Sepinggan Village}

Local wisdom in the Sepinggan village includes values or a set of rules behaviour of the Sambasness Malay in environment interactions with the society, one of it emerging in pantang larang. Pantang larang developed as a part of people oral tradition. ${ }^{21}$

Through pantang larang people expected to be wisdom towards the environment as it means from local wisdom. As we understanding, local wisdom is all shapes of knowledge, beliefs, understanding or insight, laws, even adat (custom) or ethics which leads someone and groups in the community. Refers to language, kearifan lokal known as local wisdom Local means setempat ${ }^{22}$ and wisdom means kebijaksanaan. ${ }^{23}$ Refers to the terms, kearifan lokal or local wisdom is ideas, values, views of local which contains wisdom, good values that embedded and followed by the member of people. Local wisdom refers to specific locality and community.

${ }^{19}$ Related to the belief of Malay toward things that concerned to animism and dynamism, further read on Walter William Skeat, Malay Magic (Newyork: Dover Publication, Inc., 1967).

${ }^{20}$ Munawar M. Saad dalam Yusriadi dan Patmawati (ed.), Dakwah Islam di Kalimantan Barat (Pontianak: STAIN Pontianak Press, 2006), p. 106.

${ }^{21}$ Gatot Sarmidi, "Keberadaan Wacana Pantang Larang Berlaras gender Sebagai Tradisi Lisan: Fenomena Bahasa dan Sastra Lisan Indonesia”, Jurnal Inspirasi Universitas Kanjuruhan Malang, Volume 5 Nomor 1 Tahun 2015, p. 553.

${ }^{22}$ John M. Echols dan Hassan Shadily, Kamus Inggris-Indonesia (Jakarta: Gramedia, 2006), p. 363.

${ }^{23}$ Ibid., p. 649. 
Andi M. Akhmar and Syarifuddin which quotes Putu Oka Ngakan said that local wisdom is values or local people behavior to interact with environment in wisdom way. ${ }^{24}$ It is reasonable if between one people local wisdom to another can be different. The differences caused by the difference needs and difference nature challenges. Local people experiences in sufficient their needs merged knowledge system whether relates to its environment or social. If it means the Sambasness Malay local wisdom, then it refers to all shape of knowledge, beliefs, understanding or insight, laws, even adat (custom) or ethics which leads someone and groups in the Sambasness Malay community, which can not be found in other place.

While Sonny Keraf confirmed that local wisdom is all shapes of knowledge, belief, understanding and insight even adat (custom) or behavior or ethics that leads someone behavior into its life in community or environment. All shapes of local wisdom then lived, practiced, taught and passed down from a generation to the next generations which formed human behavior patterns with it fellow, nature, even something unseen ghaib. ${ }^{25}$

Pantang larang as local wisdom of the Sambasness Malay Sepinggan village, has blend as values or unwritten rules which follow their daily as the Sambasness Malay. Indeed, for some writers, Malay and Islam is identic. As Hermansyah said, when mentioned Malay it also means adherents of Islam teachings. ${ }^{26}$ Based on this, Islam is someone Malay identity marker.

It is true, that authentically pantang larang is not recognized in Islam teachings. However, it is also understandable given the nature of Islam being flexible, so as to blend and merge with culture, time and environment society. Islam is a universal religion. This characteristics make it relevant to the culture, time and society. The universal characteristics of Islam open the opportunity of developing local wisdom among followers of Islam in the archipelago, included among the people of Malay in the Sepinggan Village. This matter shows the nature of Islam being flexible from the teachings of

${ }^{24}$ Andi M. Akhmar dan Syarifudin, Mengungkap Kearifan Lingkungan Sulawesi Selatan (PPLH Regional Sulawesi, Maluku dan Papua, Kementerian Lingkungan Hidup RI dan Masagena Press Makassar, 2007).

${ }^{25}$ Sonny Keraf, Etika Lingkungan (Jakarta: Kompas, 2006).

${ }^{26}$ Hermansyah, Islam dan Melayu..., p. 1. 
Islam, which can assimilation faster among Muslim of archipelago culture which has been embedded in their daily lives, including Malay. ${ }^{27}$

According to Hermansyah Universal characteristics of Islam teachings, especially related to values and religious common practice. ${ }^{28}$ Values and basic practice- which applied all the times and everywhere- i.e. teachings and basic values which trusted originally from God revelation which do not change and can not be changed. Because it concerns an sich teachings and basic values, then there are many things which technically unregulated. That matter necessitates teachings of Islam which originated from revelation when it intersects among people dynamic will involved human understanding of creativity and culture where teachings of Islam development. Therefore, reciprocal influence among Islam and local wisdom become fair thing. Very much in line with expression al-Islam salih fi kulli makan wa fi kulli zaman.

Certainly, not all of the elements of local wisdom can be compatible with teachings of Islam. So not all of the elements of local can be absorbed by Muslim community. Generally, elements that contradictive with the teachings of Islam are removed or replaced. The arrival of Islam indeed not to have to disconnect a society from its past, but also conserve what is good and right from it past. Awareness also cause spreaders of teachings of Islam from the past in West Kalimantan, including in the Sambas, make use of local wisdom sources in order to Islamization.

As Munawwar M. Saad discussed, ${ }^{29}$ eventhough Islam dakwa and its teaching has come and followed by the Sambasness Malay, however the influenced of traditional beliefs still attached of the community. The acknowledgement of Islam which introduce of religious understanding and maintaining old values has been long enough. Teachings of Islam which blend among values of adat (custom) has been a part of how Sambasness Malay community of religious. Similar trends, researcher has found on Malay society in the Sepinggan village.

Very much in line with the principle, al-muhafadzah 'ala al-qadm alshalih, wa al-akhdzu bi al-jadid al-ashlah (maintaining good old traditions

${ }^{27}$ Ellya Roza, Islam dan Tamaddun Melayu (Pekanbaru Riau: Daulat Riau, 2013), p. 117.

${ }^{28}$ Hermansyah, Islam dan Melayu..., p. 15.

${ }^{29}$ Munawar M. Saad in Yusriadi in Patmawati (ed.), Dakwah Islam ..., p. 105-106. 
and obtain something new and better). Refers to the principle almuhafadzah 'ala al-qadm al-shalih, wa al-akhdzu bi al-jadid al-ashlah, Muslim society become not careless of doing purification towards the existed tradition, or as well not in a hurry of adopted new things.

In a diagram, the relationship pattern between local wisdom and Islam is as follows:

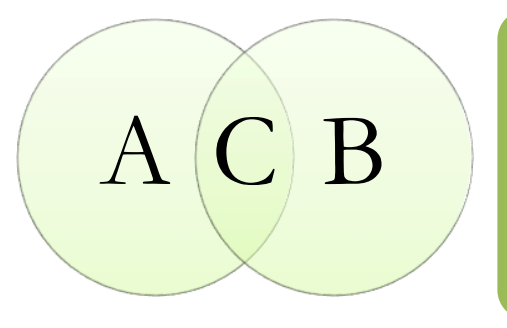

\section{Keterangan:}

$\mathrm{A}=$ local wisdom

$\mathrm{B}=$ Islam

$\mathrm{C}=$ local tradition which

combination of local tradition and

Islam

The Diagram of the pattern of relationship between local wisdom and Islam in Sepinggan Village

The pattern of the relationship between local wisdom and Islam as shown in diagram and the previous discussion above, appears in line with the development trends of teachings of Islam in Sambas Regency, ${ }^{30}$ including Sepinggan village as the place where the research was conducted. In Sepinggan village, pantang larang despite being authentically unknown in Islam, is maintained by the Muslim community in this area and integrated as values or unwritten rules that follow their daily lives as ethnic Malay. Obviously, pantang larang is not against the teachings of Islam. While pantang larang that are not in the line with the teachings of Islam have slowly been eroded and disappeared.

It should be also understood that pantang larang developing in this area is growing in a mythical condition among the people. Oral expression from generation to generation are often heard from parents, such as grandfather (nek aki), or grandmother (nek uwan). When examined carefully that the taboos or restrictions passed down from older generations

${ }^{30}$ When investigated the process of spread of da'wah of Islam in Sambas has been lasts since the arrival of the middle King to this area on 1620 M. Munawar M. Saad in Yusriadi and Patmawati (ed.), Dakwah Islam..., p. 102. 
contains wisdom and values. Obviously, the remarks in the form of words or sentences containing taboos or restrictions could allegedly from a number of cases resolved because it can be rationalized that its existence is taken for granted, passed down between generations in some situations without clear reasons.

\section{Pantang Larang and The Environmental Wisdom of Sambasness Malay In Sepinggan Village}

As local wisdom, pantang larang that developing in Sepinggan village sourced on values that inviting and teaching about how to read nature potential and rewrite tradition which accepted as universal by society. The values of local wisdom synchronized someone life in the way of appreciate, maintain, and the effort to conserve nature or environment functions. Local wisdom has noble value and developing in society also passed generation to generation.

Unwritten local wisdom, generally is a consensus or mutual agreement to run from a generation to the next generations. Therefore, someone who breaking culture and local wisdom called uncivilized, disrespectful ancestors or adat (customs).

Based on the interviews with a number of informants in Sepinggan village, obtained information kinds of pantang larang. The following information of pantang larang which contains environmental wisdom, can be described in table 1 as follows:

\section{Table 1}

\section{Pantang Larang Malay Community in Sepinggan Village \\ Related to the Environmental Wisdom}

\begin{tabular}{llll}
\hline No & \multicolumn{1}{c}{ pantang larang } & \multicolumn{1}{c}{$\begin{array}{c}\text { Consequences of } \\
\text { violation }\end{array}$} & \multicolumn{1}{c}{ Rationale } \\
\hline 1 & Frolicking in the forest & Inviting ghost & $\begin{array}{l}\text { The forest is not a } \\
\text { place to frolic }\end{array}$ \\
\hline 2 & $\begin{array}{l}\text { Reprimanding } \\
\text { something strange in } \\
\text { the forest }\end{array}$ & Being possessed & $\begin{array}{l}\text { Avoiding unseen } \\
\text { beings }\end{array}$ \\
\hline 3 & Whistling in the forest & Inviting ghost & $\begin{array}{l}\text { Avoiding unseen } \\
\text { beings or animals }\end{array}$ \\
\hline
\end{tabular}




\begin{tabular}{llll}
\hline 4 & $\begin{array}{l}\text { Taking odd things } \\
\text { found in the forest }\end{array}$ & Being followed by ghost & $\begin{array}{l}\text { Avoiding unseen } \\
\text { beings }\end{array}$ \\
\hline 5 & $\begin{array}{l}\text { Carelessly urinating in } \\
\text { the forest }\end{array}$ & $\begin{array}{l}\text { Burrut which is swelling } \\
\text { of the testicles }\end{array}$ & $\begin{array}{l}\text { Environmental } \\
\text { pollution and air } \\
\text { pollution on the forest }\end{array}$ \\
\hline 6 & $\begin{array}{l}\text { Roasting belacan } \\
\text { (shrimp paste) in the } \\
\text { forest }\end{array}$ & Inviting ghost & $\begin{array}{l}\text { Avoiding unseen } \\
\text { beings }\end{array}$ \\
\hline 7 & Urinating on graves & $\begin{array}{l}\text { Burrut which is swelling } \\
\text { of the testicles }\end{array}$ & $\begin{array}{l}\text { Avoiding unseen } \\
\text { beings }\end{array}$ \\
\hline 8 & $\begin{array}{l}\text { Torture, hitting or } \\
\text { hurting the animal for } \\
\text { pregnant women }\end{array}$ & $\begin{array}{l}\text { Children will be born } \\
\text { with disability } \\
\text { deformity (iddab). }\end{array}$ & $\begin{array}{l}\text { Importance of proper } \\
\text { treatment of animals }\end{array}$ \\
\hline 9 & $\begin{array}{l}\text { Mocking or laughing at } \\
\text { apes or monkeys }\end{array}$ & $\begin{array}{l}\text { Children will be born } \\
\text { with disability or } \\
\text { deformity (iddab), e.g } \\
\text { having a monkey's face }\end{array}$ & $\begin{array}{l}\text { Importance of proper } \\
\text { treatment of animals }\end{array}$ \\
\hline 10 & $\begin{array}{l}\text { Burying a cat after being } \\
\text { hit in an accident }\end{array}$ & $\begin{array}{l}\text { Getting a misfortune or } \\
\text { calamity }\end{array}$ & $\begin{array}{l}\text { Importance of proper } \\
\text { treatment of animals }\end{array}$ \\
\hline
\end{tabular}

Source: Adapted from a number of informants during research

Based on table 1, obviously pantang larang also related to environmental wisdom. Such as someone banned careless urinating in the forest or roasting something such belacan in the forest. Pantang larang teaching of how importance to behave among its not polluted the environment. Or, as environmental wisdom. Environmental wisdom obviously positive to develop personality or someone character. As understood, various disasters such as smog, flood, landslide, etc, are partly due to the destructive actions of man on nature. ${ }^{31}$

In this context, pantang larang suggest as control in ikhtiar of environment preserved. This line with the result of the research, that most people recognize the importance of forest and sustainability need to be

${ }^{31}$ The wrath of nature always accompanied by warning signal. As described by Syamsul Kurniawan, recently the disasters happened is harvested by the children of the nation after planting seeds of the destruction of natural ecosystem for decades. Syamsul Kurniawan, “Tanah Airku Murka”, in Pontianak Post, November 29, 2006. 
maintained, because for them the forest is the natural resources that provides for their livehood. ${ }^{32}$

\section{E. Pantang Larang in Islamic Perspective}

Pantang larang as local wisdom of Malay in Sepinggan village essentially containing values or moral message especially in order to its relationship to God, ourselves, environment and God creatures that should be embodied in the thoughts, attitudes, feelings, words and deeds, thus corresponding to norms, manners, and adat (customs). In fact, Malay community in Sepinggan village from generation to generation have made use of pantang larang as strategy to character building, especially for children and teenagers. ${ }^{33}$ Therefore, pantang larang has been taught to children at early ages in Sepinggan village. ${ }^{34}$

Character building means active efforts to shape habits, so children behavior could be shaped from an early age, from making wise and good decision also able to apllied it. Character building means carry out someone to its cognitive introduction, effectively of value appreciation, and as reality of value practice.

As Islam adherents obviously realized refers to how importance of characters, identically in terms of Islam known as akhlaq. Word of akhlaq derived from Arabic akhlaq (khuluq). Its synoym is khilqah (God created), fitrah (innate from birth), tabī'ah (already created), and wijdan (already exist in man). .35

If potential or man fitrah (i.e akhlaq) manifested in daily acts, so akhlaq into a temperament, adat (customs), deontology, or man character, in other terms akhlaq is ethics (Greek: ethos) or moral (latin: mores) means customs. ${ }^{36}$ According to Abdul Choliq Mukhtar, akhlaq is an act which is

${ }^{32}$ As Mak Anjang, Pak Usu Ijazi, Pak Angah Adul, Aning, and amount of informants on this research considering how importance the existence of the forest as source of life. Pantang larang is developing, one of them due to their views about how importance to have ethics to the environment.

${ }^{33}$ Syamsul Kurniawan, "Pantang Larang in the Sepinggan ..., p. 114.

${ }^{34}$ Syamsul Kurniawan, "Pantang Larang dalam..., p. 71.

${ }^{35}$ Muhammad Idris Abdur Rauf Al Marbawi, Kamus Marbawi (Mesir: Darul Fikr, 2002).

\footnotetext{
${ }^{36}$ Hasbullah Bakry, Sistematika Filsafat (Jakarta: Wijaya, 1970), p. 17.
} 
conducted consciously, not forced and repeated so easily without considered it. ${ }^{37}$ If the act is good is al-akhlaq al-karimah and if the act is bad is al-akhlaq al-mazmumah. Moreover, akhlaq is a kind of matter refers to state of the soul and human behaviour in connection with khaliq and makhluq, moral or immoral. In broad sense, akhlaq identic to character, cause not only related to manners of association, but also, include all activities of born and inner of human life that conducted consciously not forced in intellectual needs, biological, spiritual, social and emotional.

In a hadith described that the apostolic mission of our Prophet Muhammad Saw is the morality of akhlaq. Therefore, the discussion of character occupies the crucial position in teachings of Islam. Rasulullah said, "innamaa buitstu liuttamimma makarima al-akhlaq (HR Bukhari from Abu Daud). ${ }^{38}$ The word "Innamaa" function as limit of Rasulullah tasks that is to perfect the glory of akhlaq. While "utammimma" means perfecting. This matter contains meaning that seeds of nobility already in each of every human, Rasulullah only developing and perfecting it.

Character building in view of Islam means manifested akhlaq on someone in thinking, acting, and to social behave refers to values of sublime which become identity, realized in its interaction to Allah Swt., among others and its environment as manifested Allah Swt servant at once as khalifah on earth. In Islam, character have an important situation and considered have a crucial function leading life of the community.

Akhlaq toward the environment is one of crucial of teachings of Islam. Environmental wisdom in line with five things which is greatly guarded of teachings of Islam: first, protecting the environment similar as protecting religion, run the command of Allah to be fair, and do good. ${ }^{39}$ Second, protecting the environment similar as protecting soul, protection against life and their safety. In Islam, a case of murdering a soul considered as a great sin,

${ }^{37}$ Abdul Choliq Muchtar, Hadits Nabi dalam Teori dan Praktek (Yogyakarta: THPress, 2004), p. 32

${ }^{38}$ Jalaluddin Suyuti, Jami' al-Shagir (Mesir: Dar al-Qalam,1966), p. 92.

39 "And cause not corruption upon the earth after its reformation and Invoke Him in fear and aspiration indeed the mercy of Allah is near to the doers of good" (QS Al-A'raf/07: 56).

"Indeed Allah orders justice and good conduct and giving to relatives and forbids immorality and bad conduct and oppression. He admonishes you that perhaps you will be reminded" (QS al-Nahl/ 16: 90). 
also forbidden to have a suicide. The damaged of environment could give the bad impact for human health, the victims of floods, landslides, disease cost of air pollution, water, food, etc. ${ }^{40}$ Third, protecting environment includes an effort to protect sustainability of human offspring in the future. ${ }^{41}$ For example: save water and protecting the source of water from polluted is an effort to protect the availability of water for the future generation. It is predicted around next 40 years many countries collide over the source of water because of its scarcity. Today, some part of hemisphere of most human hard to get clean water. Fourth, protecting environment equals protecting mind. Better environment, fresh air, will help better developing of the brain. At the opposite, based on the research the polluted environment will decreased IQ of a child. Fifth, protecting environment means protecting treasure. Allah SWT making the universe as treasure for human being on the earth. Earth, trees, animals, water, the energy sources, etc is kinds of treasure. The destruction of environment means damaging the source of human living that Allah has given.

The nature does not belong to human but it is belong and created of God. Nature has balance and regularity (sunatullah) and responsible is handed over to human in utilization and management that based on morality and faith. ${ }^{42}$ It means, human as khalifah fi al-ard perform the duties must following the leads of Quran to match will by Allah. So, the development of science and technology for utilization of nature functions and the environmental conservation must be controlled according to instructions of Allah Swt. If not, the development of science and technology that is uncontrolled, will not bring tranquility, enjoyment, and convenience in life, it has resulted disaster occurrence which to bring suffering for mankind and its environment. ${ }^{43}$

40 "For that causes We decreed for the Children of Israel that whose ever killeth a human being for other than manslaughter or corruption in the earth, it shall be as if he had killed all mankind, and whose saveth the life one, it shall be as if he had saved the life of all mankind. Our messengers came unto them of old with clear proofs (of Allah's Sovereignity), but afterwards many of them became prodigals in the earth” (QS Al Maidah/ 05: 32).

${ }_{41}^{41}$ indeed, if you leaving your children in a rich state its better than leaving them in a poor state and begging on others" (Al- Bukhari and Muslim).

${ }^{42}$ Agus Abu Aufa, "Fikih Keluarga”, in Majalah Nikah Sakinah, Vol. 9 No. 10, Januari 2011.

${ }^{43}$ Ahmad Baiquni, “Tugas Ganda Manusia” in Iqra' (Yogyakarta: Salahuddin Press, 1985). 
Based on this, pantang larang that is developing among Sambasness Malay in the Sepinggan village, though not native to Islam, but in line with the teachings of Islam. Refers to the writer, pantang larang that is developing among Sambasness Malay in the Sepinggan village, most of its suggest how importance building good relationship with the environment, that is in line with the teachings of Islam.

\section{F. Conclusion}

Based on the research, it can be concluded that Malay community in Sepinggan village knowing pantang larang as values or unwritten rules about to behave and to interact in daily lives. As local wisdom that developing in community, pantang larang has been used since long ago as a strategy for character building, especially for children and teenagers.

Pantang larang is a set of dos and donts to do. There is also taboos. If someone breaking pantang larang its consequences to accept a bad effect or terrifying. Pantang larang includes values or moral message in order to its relationship to God, ourselves, environment and God creatures that should be embodied in the thoughts, attitudes, feelings, words and deeds, thus corresponding to norms, manners, and adat (customs). Among kinds of pantang larang, there is related to environmental wisdom, such as frolicking in the forest, reprimanding something strange in the forest, whistling in the forest, taking odd things found in the forest, carelessly urinating in the forest, roasting belacan in the forest, urinating on graves, torture hitting or hurting the animal for pregnant women, mocking or laughing apes or monkeys, and burying a cat after being hit.

Based on the study of pantang larang that related to environmental wisdom, pantang larang still relevant to build values of characters and not contradictory of teachings of Islam. Moreover, pantang larang which developing between Sambasness Malay in Sepinggan village, most of it teaching refers to how importance to behave toward environment, is in line to teachings of Islam which very emphasize how importance concern toward environment.

Pantang larang relevant as strategy for character building, especially children and teenagers of the community - in this case, Malay - that traditionally relative and admitted local wisdom as in Sepinggan village Sambas Regency. Also, be concluded that through pantang larang, people 
Syamsul Kurniawan

has been contributed in the efforts of formation and development of character sourced on local wisdom. [ ] 


\section{REFERENCES}

Akhmar, Andi M, and Syarifudin, Mengungkap Kearifan Lingkungan Sulawesi Selatan, PPLH Regional Sulawesi, Maluku and Papua, Ministry of Environment of RI and Masagena Press Makassar, 2007.

Aufa, Agus Abu, "Fikih Keluarga", in Majalah Nikah Sakinah, Vol. 9 No. 10, Januari 2011.

Baiquni, Ahmad, “Tugas Ganda Manusia” in Iqra', Yogyakarta: Salahuddin Press, 1985.

Bakry, Hasbullah, Sistematika Filsafat, Jakarta: Wijaya, 1970.

Bothoul, Gasthoul, Teori-Teori Filsafat Sosial Ibn Khaldun, Jakarta: Titian Ilahi Press, 1998.

Depag RI, Al-Qur'an dan Terjemahannya, Semarang: Thoha Putra, 1989.

Echols, John M. and Hassan Shadily, Kamus Inggris-Indonesia, Jakarta: Gramedia, 2006.

Hartini and Kartasapoetra, Kamus Sosiologi dan Kependudukan, Jakarta: Bumi Aksara, 1992.

Hermansyah, Islam dan melayu di Borneo, Pontianak: IAIN Pontianak Press, 2015.

Keraf, Sonny, Etika Lingkungan, Jakarta: Kompas, 2006.

Kurniawan, Syamsul, “Tanah Airku Murka”, in Pontianak Post, November 29, 2006.

Kurniawan, Syamsul "Konsep dan Implementasi Pendidikan Karakter di Lingkungan Keluarga, Sekolah dan Masyarakat", Journal of AtTurats, Volume 6, Nomor 1, December 2012.

Kurniawan, Syamsul, Pendidikan Karakter, Yogyakarta: Arruzz Media, 2013.

Kurniawan, Syamsul, "Penguatan Kearifan Lingkungan Melalui Pelajaran Pendidikan Agama Islam di Sekolah”, Journal of At-Turats, Volume 7, Nomor 2, December 2013.

Kurniawan, Syamsul, "Pantang Larang in the Sepinggan Village Muslim Community from the Perspective of Character Education", Journal of Ta'dib, Volume 21, Number 2, December 2016. 
Kurniawan, Syamsul, "Pantang Larang dalam Pendidikan Karakter Pada Anak Usia Dini Orang Melayu Sambas Desa Sepinggan”, in International Conference Proceeding, IAIN Pontianak, April 2017.

Kutanegara, Pande Made, Membangun Masyarakat Indonesia Peduli Lingkungan, Yogyakarta: Gadjah Mada University Press, 2014.

Al Marbawi, Muhammad Idris Abdur Rauf, Kamus Marbawi, Mesir: Darul Fikr, 2002.

Muchtar, Abdul Choliq, Hadits Nabi dalam Teori dan Praktek, Yogyakarta: TH-Press, 2004.

Nasiana, and friends., Asal-Usul Sepinggan: Antologi Cerita Rakyat Semparuk, Pontianak: The Language Development of West Kalimantan, 2016.

Roza, Ellya, Islam dan Tamaddun Melayu, Pekanbaru Riau: Daulat Riau, 2013.

Sarmidi, Gatot, "Keberadaan Wacana Pantang Larang Berlaras gender Sebagai Tradisi Lisan: Fenomena Bahasa dan Sastra Lisan Indonesia”, Journal of Inspiration of Kanjuruhan, Malang University, Volume 5 Nomor 1, 2015.

Skeat, Walter William, 1967. Malay Magic, Newyork: Dover Publication, Inc., 1967.

Soekamto, Soerjono, Kamus Sosiologi, Jakarta: Rajawali Press, 1993.

Suyuti, Jalaluddin, Jami' al-Shagir, Mesir: Dar al-Qalam, 1966.

Wiriadinata, Wahyu, "The Indonesian Forestry in Economic, Ecosystem and Legal Perspectives", Journal of Public Administration and Governance, Vol. 4, No. 1, 2014. p. 87-100.

Yusriadi and Patmawati (ed.), Dakwah Islam di Kalimantan Barat, Pontianak: STAIN Pontianak Press, 2006.

Kompas, "Setiap Tahun Hutan Indonesia Hilang 684.000 Hektar", http://regional.kompas.com/read/2016/08/30/15362721/setiap.t ahun.hutan.indonesia.hilang.684.000.hektar.

Melissa Hogenboom, "Melacak Para Pemburu Orang Utan di Kalimantan”, http://www.bbc.com/indonesia/vert-earth-38787128. 